\title{
Evaluation of Self-esteem in Nursing Teachers at Public and Private Universities $^{1}$
}

\author{
Fábio de Souza Terra² \\ Maria Helena Palucci Marziale ${ }^{3}$ \\ Maria Lúcia do Carmo Cruz Robazzi ${ }^{3}$
}

\begin{abstract}
The aim of this study was to evaluate the self-esteem of Nursing faculty in public and private universities and compare the measures presented by two groups of teachers. This descriptive, correlational, cross-sectional quantitative study was conducted with 71 teachers from two universities (public and private) from a municipality in the south of the State of Minas Gerais. After pilot testing and validation, A questionnaire and the Rosenberg Self-Esteem Scale were used. It was found that most teachers had high self-esteem, with no significant difference between the two groups. When the continuous scores on this scale were analyzed, there was a significant difference between universities, showing that the private university teachers had lower selfesteem scores. The Rosenberg Self-Esteem Scale showed high value for coefficient alpha. It was concluded that self-esteem was high predominantly in the studied teachers, but those from the private university had lower scores. These data may help institutions to reflect on the issue and invest in building healthy environments, with the worker/teacher of Nursing as the protagonist, which represents advancement in the knowledge of the subject in the field of Nursing.
\end{abstract}

Descriptors: Faculty Nursing; Universities; Education Higher; Occupational Health; Self-esteem.

\footnotetext{
${ }^{1}$ Paper extracted from Doctoral Dissertation "Avaliação da ansiedade, depressão e autoestima em docentes de Enfermagem de universidades pública e privada" presented to Escola de Enfermagem de Ribeirão Preto, Universidade de São Paulo, Centro Colaborador da OMS para o Desenvolvimento da Pesquisa em Enfermagem, Brasil. This research was supported by Coordenação de Aperfeiçoamento de Pessoal de Nível Superior, (CAPES).

2 PhD, Adjunct Professor, Escola de Enfermagem, Universidade Federal de Alfenas, Brazil.

${ }^{3}$ PhD, Full Professor, Escola de Enfermagem de Ribeirão Preto, Universidade de São Paulo, WHO Collaborating Centre for Nursing Research Development, Brazil.
}

Corresponding Author:

Fábio de Souza Terra

Universidade Federal de Alfenas. Escola de Enfermagem

Rua Gabriel Monteiro da Silva, 700

Centro

CEP: 37130-000, Alfenas, MG, Brasil

E-mail: fabio.terra@unifal-mg.edu.br 


\section{Avaliação da autoestima em docentes de enfermagem de universidades pública e privada}

Objetivo: avaliar a autoestima em docentes de enfermagem de universidades pública e privada e comparar as medidas apresentadas pelos dois grupos de professores. Método: trata-se de pesquisa descritiva, correlacional, transversal, quantitativa, desenvolvida com 71 docentes de duas universidades (pública e privada) de um município do sul do Estado de Minas Gerais. Utilizaram-se um questionário, após validação e teste piloto, e a Escala de Autoestima de Rosenberg. Resultado: constatou-se que a maioria dos docentes apresentou autoestima alta, não havendo diferença significativa entre os dois grupos. Analisando-se os escores contínuos dessa escala, observou-se diferença significativa entre as universidades, mostrando que os docentes da universidade privada apresentaram escores mais baixos de autoestima. A Escala de Autoestima de Rosenberg apresentou valor alto de coeficiente alfa. Conclusão: a autoestima alta foi predominante nos professores estudados, mas os da universidade privada apresentaram escores mais baixos. Esses dados podem auxiliar as instituições a refletir sobre o assunto e investir na construção de ambientes saudáveis, tendo como protagonista o trabalhador/ docente de enfermagem, representando avanços para o conhecimento da temática na área de enfermagem.

Descritores: Docentes de Enfermagem; Universidades; Educação Superior; Saúde do Trabalhador; Autoestima.

\section{Evaluación de la autoestima en docentes de enfermería de universidades pública y privada}

Objetivo: evaluar la autoestima de profesores de Enfermería en universidades pública y privada y comparar las medidas presentadas por los dos grupos de profesores. Método: Se trata de una investigación descriptiva, correlacional, transversal, cuantitativa, desarrollada con 71 profesores de dos universidades (pública y privada) de un municipio en el sur del estado de Minas Gerais, Brasil. Se utilizó un cuestionario, tras prueba piloto y validación, y la Escala de Autoestima de Rosenberg. Resultado: Se encontró que la mayoría de los profesores tenía autoestima alta, sin diferencia significativa entre los dos grupos. Cuando se analizaron los resultados continuos en esta escala, fue encontrada una diferencia significativa entre las universidades, que muestra que los profesores universitarios privados tenían puntuaciones más bajas de autoestima. La Escala de Autoestima de Rosenberg mostró un alto coeficiente alfa. Conclusión: La autoestima alta predominó entre los profesores estudiados, pero aquellos de la universidad privada tuvieron puntuaciones más bajas. Estos datos pueden ayudar a las instituciones a reflexionar sobre el tema e invertir en la construcción de entornos saludables, en que el trabajador/profesor de Enfermería sirva como protagonista, lo que representa avances para el conocimiento sobre el tema en el área de Enfermería.

Descriptores: Docentes de Enfermería; Universidades; Educación Superior; Salud Laboral; Autoestima.

\section{Introduction}

The work market in the field of health has undergone important transformations, determined by economic, technological and social policies. These transformations demand changes in the teaching/training institutions, so that alumni from the universities meet the new demands generated $^{(1)}$.

Among the multiple work environments in the educational area and the various types of university activities, those developed by persons who work in Nursing are included.
In Brazil, there are two types of universities: public and private. One starts with the supposition that the identity of teachers at private Higher Learning institutions (HLS) have suffered strong repercussions from the transformations in the world of work and in the changes relative to the process of expansion of these institution in Brazil since the 1990s. ${ }^{(2)}$.

The professional responsible for education at the universities is the teacher. The work he/she does 
consists of a set of specific actions that are performed by the professor in person during his/her professional life. Therefore, he/she is the transmitter of contents, concerned about fulfilling objectives, goals and time schedules, with a view to producing a product for the work market ${ }^{(3)}$.

There are various situations in this work environment, mentioned by teachers, such as the repetitive work; stressful environment, accelerated rhythm, continuous monitoring and the pressure from the directors/bosses, among others, which may become harmful to the workers ${ }^{(4)}$.

In the teaching of Nursing, there appear to be more factors that make things difficult than those that facilitate the work. There are impedimental factors related to the work, such a labor organization, work demands, lack of access to health services and remuneration. Therefore, these teachers tend to become ill, which certainly will affect their work life, with harm in relation to their health and condition of worker(5).

Thus, the working conditions of these persons; that is to say, the circumstances under which they mobilize their physical, cognitive and affective capacities to attain the objectives of scholarly production, may easily demotivate them and generate alterations in their psychophysiological functions. If there is no time for recovery, they may trigger clinical symptoms, making it possible for changes to occur in their self-esteem ${ }^{(6)}$.

Self-esteem is defined as a positive or negative orientation in one's own direction, an overall evaluation of one's own value. Persons motivated to have high self-esteem present indications of a positive selfconsideration, which may be developed by means of the day to day experiences of each individual. It is a component of self-concept, defined as the totality of the individual's thoughts and feelings having reference to himself [sic] as an object ${ }^{(7)}$.

It is worth pointing out that self-esteem has equally been related to social performance, since it can influence the expectations that people have about the result of their own performance ${ }^{(8)}$.

In view of these considerations, and by virtue of the reduced number of international, and particularly Brazilian studies with reference to this subject among Nursing teachers, the option was taken to conduct this study with the aim of evaluating the self-esteem among Nursing teachers at public and private universities in a municipality in the south of the State of Minas Gerais, and compare the measures presented by the two groups of teachers.

\section{Method}

This was a descriptive, correlational, cross-sectional study with a quantitative approach, conducted with 71 teachers of the undergraduate course in Nursing at two Universities (39 from the public and 32 from the private university) located in the municipality of Alfenas (Minas Gerais), Brazil. Of the 75 teachers of the Nursing Course of the two universities, only two teachers from each university did not participate in the study, because they were away from teaching activities due to pregnancy/ maternity, or were no longer doing the post-graduation course.

Data collection occurred at the end of the first semester of the school year of 2010; that is to say in the month of June. For this stage, a semi-structured questionnaire was used, containing sociodemographic, work activity, and life habit variables. This instrument was submitted to a process of refinement by means of evaluation by five judges: two researchers who were specialists on the subject of Workers' Health, two with experience in the construction and validation of research instruments, and one with experience in the subject of Workers' Health and in construction and validation of research instruments. Afterwards, it was submitted to a pilot test with ten randomly selected teachers in the Undergraduate Course in Nursing of a public HLI in the State of São Paulo, with the aim of verifying how the questions were understood by the subjects and the need for adjusting the vocabulary.

For the evaluation of self-esteem the Rosenberg Self-Esteem Scale was used. The original instrument in English, was elaborated by Rosenberg in 1965, translated and validated for Portuguese in $2001^{(9)}$.

It is a 4 point scale of the Likert type, containing 10 items for the evaluation of self-esteem by means of a single dimension. Of the 10 affirmatives, 5 evaluated the individual's positive feelings about him/herself and the others evaluated negative feelings. The score is calculated and the points obtained are added by means of the evaluation of the 10 phrases, totaling a single value for the scale. The possible interval of this scale ranges from 10 (10 items multiplied by value 1 ) to 40 (10 items multiplied by value 4$)^{(10)}$.

The self-esteem classification is defined by the following scale: high self-esteem (satisfactory) -a score higher than 30 points; medium - a score between 20 and 30 points and low (unsatisfactory) - a score lower than 20 points $^{(9)}$.

The study was approved by the Research Ethics 
Committee of the School of Nursing of Ribeirão Preto, University of São Paulo, according to Protocol No. 0900/2008. Previous authorization was requested from the Dean and coordinators of the undergraduate course in Nursing of the Universities under study. In addition the teachers of Nursing who participated in the study were asked to sign a Term of Free and Informed Consent, and their anonymity and the right to desist at any stage whatever was guaranteed, in accordance with Resolution 196/96, which deals with Research Involving Human Beings.

After collection, the data were tabulated in the program Software Statistical Package for Social Science (SPSS) version 15.0, for descriptive statistical and inferential analysis. The Kolmogorov-Smirnov test was performed and asymmetrical distribution of the variables analyzed was found. Comparisons were made between the measures (continuous scores) of self-esteem of the teachers of Nursing at the public university and those at the private university, applying the Mann-Whitney test.

After this, bivariate analysis was performed, comparing the independent variables with the measure of self-esteem, by application of Pearson's Chi-square or Exact Fisher tests for comparison of proportions, and Mann-Whitney, for comparison of numerical variables (continuous). For all the above-mentioned variables, the Odds Ratio was calculated. The level of significance of $5 \%$ was considered; that is the data were statistically significant for $\mathrm{p}<0.05$.

After bivariate analysis, the variables with $p$-value lower than 0.25 in the univariate analyses were selected for the multiple binary logistic regression models. The adjustment of the final model was evaluated by means of the Hosmer \& Lemeshow statistics. When no logistic regression model was found, the option was taken for a second type of multivariate analysis, denominated Decision Tree. Lastly, to evaluate the reliability of the Rosenberg Self-Esteem Scale, an analysis of internal consistency was performed by means of Cronbach's Alpha Coefficient.

\section{Results}

As a result, a predominance of teachers of the female sex was found; in the age-range from 31 to 40 years; Catholics; married; monthly family income from $\mathrm{R} \$ 4001$ to $\mathrm{R} \$ 6000$ (Brazilian Reais); home ownership; University education in Nursing, master's degree; with time of working in teaching from 6 to 10 years, and at the present institution, from 1 to 5 years. Some of the teachers practiced physical exercises on a weekly basis, and others were sedentary. Few were smokers and the majority did not consume alcoholic beverages, presented no chronic diseases, and did not make daily use of medications. The occurrence of a remarkable event in life (loss/death of a loved one and diagnosis of disease in a loved one) and in the teaching career (accumulation of responsibilities/jobs and lack of professional recognition) was frequent among the subjects evaluated.

The Rosenberg Self-Esteem Scale presented a high value for Alpha coefficient, 0.907. Therefore, the internal consistency of this scale was considered very good and acceptable for the items evaluated and highly correlated with one another, indicating homogeneity.

Table 1 - Distribution of teachers of Nursing according to the self-esteem classification based on cut-off points. Public and Private Universities in Alfenas, MG, Brazil, 2010

\begin{tabular}{lccc}
\hline $\begin{array}{l}\text { Classification } \\
\text { of self-esteem }\end{array}$ & $\begin{array}{c}\text { Public University } \\
(\mathbf{n}=\mathbf{3 9})\end{array}$ & $\begin{array}{c}\text { Private University } \\
(\mathbf{n}=\mathbf{3 2})\end{array}$ & $\begin{array}{c}\text { Total } \\
(\mathbf{n}=\mathbf{7 1})\end{array}$ \\
\hline High & $31(79.5 \%)$ & $21(65.6 \%)$ & $52(73.2 \%)$ \\
Medium & $7(17.9 \%)$ & $11(34.4 \%)$ & $18(25.4 \%)$ \\
Low & $1(2.6 \%)$ & $0(0.0 \%)$ & $1(1.4 \%)$ \\
\hline
\end{tabular}

$\mathrm{p}$-Value of Exact Fisher test $=0.170$ (in the comparison between the universities)

With regard to the classification of self-esteem, based on the cut-off points, there was no significant difference between the two groups $(p=0.170)$, as the mean percentage of self-esteem was $17.9 \%$ in the public university teachers and $34.4 \%$, in those from the private university. There was low self-esteem in only one teacher from the public university $(2.6 \%)$ (Table 1 ).

When the continuous scores of the self-esteem scale were analyzed, significant difference was observed between the universities $(p=0.008)$, showing that the teachers from the private university presented lower scores in the measures of self-esteem when compared with those from the public university.

In this study it was found that none of the variables analyzed [type of university, sex, age-range, religious belief, marital status, monthly family income, number of children, type of dwelling, university education, title, having more than one degree, time since graduation, time of working in teaching, time of working at the present HLI, type of work contract at the HLI, weekly hourly load at the institution, career plan at the HLI and other fixed job in addition to the teaching activity] showed significant association with self-esteem $(p>0.05)$. Only the variables type of university, monthly family income and career plan at the HLS showed some trend towards 
this association $(p=0.189, p=0.167$ and $p=0.189$, respectively). It is pointed out that the teachers at the private university had greater chance of present low or medium self-esteem.

Table 2 - Bivariate analysis of the factors associated with self-esteem according to the variables practice of physical exercises, smoking, alcoholic beverage consumption, presence of chronic disease and daily use of medications. Public and Private Universities in Alfenas, MG, Brazil, 2010

\begin{tabular}{|c|c|c|c|c|c|c|}
\hline Variables & High Self-Esteem & $\begin{array}{c}\text { Low or Medium Self- } \\
\text { Esteem }\end{array}$ & Value-p & OR & \multicolumn{2}{|c|}{ IC $95 \%$} \\
\hline \multicolumn{5}{|c|}{ Practice of physical exercise } & & \\
\hline Sedentary(a) & $15(60.0 \%)$ & $10(40.0 \%)$ & $0.063^{*}$ & 1.00 & & \\
\hline Practice activity & $37(80.4 \%)$ & $9(19.6 \%)$ & & 0.36 & 0.12 & 1.08 \\
\hline \multicolumn{7}{|l|}{ Smoking } \\
\hline No & $49(72.1 \%)$ & $19(27.9 \%)$ & $0.559^{\dagger}$ & & & \\
\hline Yes & $3(100.0 \%)$ & $0(0.0 \%)$ & & $\ddagger$ & & \\
\hline \multicolumn{7}{|c|}{ Consumption of alcoholic beverages } \\
\hline No & $27(69.2 \%)$ & $12(30.8 \%)$ & $0.400^{*}$ & 1.00 & & \\
\hline Yes & $25(78.1 \%)$ & $7(21.9 \%)$ & & 0.63 & 0.21 & 1.85 \\
\hline \multicolumn{7}{|c|}{ Presence of chronic disease } \\
\hline No & $39(76.5 \%)$ & $12(23.5 \%)$ & $0.326^{*}$ & 1.00 & & \\
\hline Yes & $13(65.0 \%)$ & $7(35.0 \%)$ & & 1.75 & 0.57 & 5.38 \\
\hline \multicolumn{7}{|l|}{ Daily use of Medications } \\
\hline No & $36(80.0 \%)$ & $9(20.0 \%)$ & $0.090^{*}$ & 1.00 & & \\
\hline Yes & $16(61.5 \%)$ & $10(38.5 \%)$ & & 2.50 & 0.85 & 7.33 \\
\hline
\end{tabular}

Table 2 shows that no analyzed variable showed significant association with self-esteem ( $p>0.05)$; only the variable practice of physical activity presented association within the threshold $(p=0.063)$, as the teachers who practiced physical activity had lower prevalence of low or medium self-esteem (19.6\%). It is also pointed out that the variable daily use of medications presented some trend towards this association $(p=0.090)$.

Table 3 - Bivariate analysis of the factors associated with self-esteem according to the occurrence of a remarkable event in life or teaching career. Public and Private Universities in Alfenas, MG, Brazil, 2010

\begin{tabular}{|c|c|c|c|c|c|c|}
\hline Variables & High Self-Esteem & Low or Medium Self-Esteem & Value-p & OR & \multicolumn{2}{|c|}{ IC $95 \%$} \\
\hline No & $36(85.7 \%)$ & $6(14.3 \%)$ & $0.004^{*}$ & 1.00 & & \\
\hline Yes & $16(55.2 \%)$ & $13(44.8 \%)$ & & 4.87 & 1.57 & 15.13 \\
\hline \multicolumn{7}{|c|}{ Occurrence of remarkable event in the career of teacher } \\
\hline No & $29(85.3 \%)$ & $5(14.7 \%)$ & $0.028^{*}$ & 1.00 & & \\
\hline Yes & $23(62.2 \%)$ & $14(37.8 \%)$ & & 3.53 & 1.11 & 11.24 \\
\hline
\end{tabular}

*Application of Pearson's Chi-square Test; OR=Odds Ratio; IC=Interval of Confidence

Table 3 shows that the variables occurrence of remarkable event in life and occurrence of remarkable event in the career of teacher were significantly associated with self-esteem $(p=0.004$ and $p=0.028$, respectively). By the odds ratio it was verified that the teachers who had had some remarkable event in life and also in the career as teacher, had greater chance of presenting low or medium self-esteem.

All the variables with $\mathrm{p}$-value $<0.25$ in the bivariate analysis (type of university, monthly family income, weekly hourly load, practice of physical exercises, type of work contract, career plan at the HLI, daily use of medications and occurrence of remarkable event in life and in teaching career) were included in the multivariate model of the binary logistic regression, with the response variable being self-esteem.

The variables occurrence of remarkable event in life and occurrence of remarkable event in the career of teacher remained in the final logistic regression model. Thus, it was found that a teacher who had some 
remarkable event in life had 5 times more chance of presenting medium or low self-esteem than one who did not have this event. When this concerned some remarkable event in the teaching career, this chance fell to 3.80. This model had good adjustment according to the Hosmer \& Lemeshow test.

According to the multivariate analysis by means of the decision tree, the variables occurrence of remarkable event in life and daily use of medications remained in the final model, indicating that the higher prevalence of medium or low self-esteem is associated with the occurrence of remarkable event in life and the daily use of medications. The model presented had good adjustment, correctly classifying $78 \%$ of the data.

\section{Discussion}

Self-esteem concerns the positive or negative evaluation the individual makes of himself/herself, therefore constituting a central aspect of the I, which plays a fundamental role in the construction of adult identity. Moreover, it is considered the evaluative component of self-concept, which includes cognitive and behavioral, as well as evaluative and affective aspects ${ }^{(11)}$.

In the present study the frequency of medium selfesteem among the teachers evaluated was $34.4 \%$ at the private and $17.9 \%$ at the public university; and one teacher at the public institution presented low selfesteem. Investigation into the mental health of teachers of the Primary and High School throughout the country, covering 1.440 schools and 30 thousand teachers, found that $26 \%$ of the studied sample presented emotional exhaustion, with low self-esteem being the main factor for the configuration of this condition(12).

It should also be emphasized that it is well known that the self-esteem of individuals may be influenced by social characteristics such as sex, age and marital status. The research found that self-esteem was negatively correlated with age or that it increased with aging, with elderly persons having higher self-esteem(13).

In this study it was found that the variable practice of physical activity presented association within the threshold with self-esteem, showing that the teachers who practiced physical activity had lower prevalence of low or medium self-esteem. Physically active individuals tend to have better health, more positive attitudes in relation to work and reveal greater capacity to deal with stress, thus presenting a higher self-esteem ${ }^{(14)}$.

In the context of the university, the teacher's day to day experience is conflicting and agitated and it is possible to have problems with students. There are a series of responsibilities that may be listed, such as: planning tasks, providing guidance; providing services to the community; assistance and consultations; commitment to the discovery of new knowledge and its dissemination; participation in commissions, lectures, among others. All these factors may be associated with alterations in their self-esteem ${ }^{(15)}$.

The Manual of Procedures for Health Services of the Ministry of Health and the Pan American Health Organization point out risk factors of an occupational nature known to involve alterations in self-esteem. Among these appear successive deceptions in work situations, losses accumulated over the course of years of work, loss of the work position and being dismissed ${ }^{(16)}$.

In addition, it is pointed out that alterations in selfesteem may be associated with environmental stress factors. The authors identified six categories that group the potentially stressing factors in the occupational environment of the university: a) lack of administrative support; b) the relationship with the students; c) the relationship with colleagues; d) work overload; e) financial insecurity f) lack of recognition(17). Little recognition of the work developed is related by teachers of Nursing as a stressful factor during their performance in clinical fields ${ }^{(18)}$. It should be pointed out that in the present study it was verified that the teachers who had had some remarkable event in life and also in the career as teacher, had greater chance of presenting low or medium self-esteem.

A study conducted with Swiss teachers identified that the major cause of changes in self-esteem, with a state of feeling professionally worn out/or/with professional burnout, was poor teacher-student relationship ${ }^{(19)}$. On the other hand, the survey conducted with primary school teachers in Belo Horizonte (MG) revealed that some teachers considered that they had a poor relationship in their work with students $(13 \%)$, colleagues $(14 \%)$, superiors $(20 \%)$ and with students' parents $(26 \%)^{(20)}$. In view of the foregoing, it is possible to observe that teachers, among them those at universities, are exposed to various psychosocial risk factors, which present the potential to cause physical, social and psychological harm, capable of altering their self-esteem(21).

In this study, it was observed that the teachers at the private university presented a median of lower selfesteem scores. In view of this fact, it should be mentioned that the teachers at private schools are submitted to work and organization processes differing from those existent at public schools; which may cause frequent salary distortions, insecurities and uncertainties ${ }^{(22)}$. 
Furthermore, in this context, the identity of teachers at HLI will be constituted at the intersection of social relationships and the recognition of society. However, it was found that elements such as disenchantment and suffering are common among teachers in the day to day confrontation of institutions and educational management. It is in this sense that the identities of teachers at private HLIs has been constructed, permeated by the anguish surrounding the question of being dismissed, associated with failure as regards their career or exercising the profession ${ }^{(2)}$.

Although there has been an increase in the demand for undergraduate courses in absolute terms, as the offer is also undergoing expansion, especially the private offer, in relative terms the demand of students for private institutions is undergoing retraction, which may be proved by the reduction in the candidates: vacancy ratio in this segment. On the other hand, this ratio in public institutions has shown an opposite movement. The teacher at the private university begins to fear being dismissed because there are no new groups in the course he/she teaches, which is not observed to a great extent in the teachers at public HLIs, due to the fact that they have permanent jobs ${ }^{(23)}$. Thus, the insecurity at work contributes to the use of the escape strategy to face the situation, which involves pessimism that has been considered the precursor of low self-esteem ${ }^{(24)}$.

It is important to point out that there are few published results involving teachers at the level of higher education, particularly in the area of Nursing(25). This lack of investigations on this subject made it difficult to compare the results of the present study with others. However, in some situation, comparison of the data of this research occurred with those originated from studies with teachers of primary and middle school education.

The main limitations of this study, which deserve to be pointed out, include the cross-sectional design of the research and sample size. Nevertheless, as an initial exploratory research, the study attained its objectives, demonstrating the reality of the studied teachers, since the data found may help reflection on the subject and the institutions to invest in the construction of healthy environments, with the worker/teacher of Nursing as protagonist, which represents advancements for the knowledge of the subject in the field of Nursing.

\section{Conclusion}

High self-esteem was predominant in the studied teachers, however, some presented medium or low self-esteem. When the continuous scores of the scale were analyzed, the teachers from the private university presented lower self-esteem scores, when compared with those from the public university.

It is up to the teaching institutions to implement feasible practices that favor the health of their teachers, and to adopt preventive strategies directed towards these teachers, to reduce the risks of the work environment. In addition it is important to elaborate favorable conditions for health promotion; that is to say, interventions that promote beneficial results for the teachers at a psychological and physiological level, minimizing the effects of events that generate alterations in self-esteem.

In view of the foregoing, it is necessary to conduct further studies, particularly longitudinal research, at other Brazilian and international universities, in order to try to gain a deeper understanding of the factors that are connected with the activities of the teacher of Nursing and the changes in self-esteem, to explain this association.

\section{References}

1. Donati L, Alves MJ, Camelo SHH. O perfil do estudante ingressante no curso de graduação em enfermagem de uma faculdade privada. Rev Enferm UERJ. [periódico na Internet]. 2010 [acesso 2 set 2010]; 18(3): 44650. Disponível em: http://www.facenf.uerj.br/v18n3/ v18n3a19.pdf

2. Siqueira TCA. O trabalho docente nas instituições de ensino superior privado em Brasília. Soc estado [periódico na Internet]. 2006 [acesso 15 set 2010]; 21: 803-18. Disponível em: http://www.scielo.br/pdf/se/ v21n3/a19v21n3.pdf

3. Silva MG, Ruffino MC. Comportamento docente no ensino de graduação em Enfermagem: a percepção dos alunos. Rev. Latino-Am. Enfermagem. [periódico na Internet]. 1999 [acesso 10 out 2010]; 7(4): 4555. Disponível em: http://www.scielo.br/pdf/rlae/ v7n4/13488.pdf

4. Reis EJFB, Carvalho FM, Araújo TM, Porto LA, Silvany Neto AM. Trabalho e distúrbios psíquicos em professores da rede municipal de Vitória da Conquista, Bahia, Brasil. Cad Saúde Pública. [periódico na Internet]. 2005 [acesso 5 out 2010]; 21(5): 1480-90. Disponível em: http://www.scielo.br/pdf/csp/v21n5/21.pdf

5. Soares RJO, Zeitoune RCG, Lisboa MTL Mauro MYC. Fatores facilitadores e impeditivos no cuidar de si para docentes de Enfermagem. Texto Contexto-Enferm. [periódico na Internet]. 2011 [acesso 28 jul 2012]; 
20(4):758-65. Disponível em: http://www.scielo.br/ pdf/tce/v20n4/15.pdf

6. Gasparini SM, Barreto SM, Assunção AA. O professor, as condições de trabalho e os efeitos sobre sua saúde. Educ Pesqui. [periódico na Internet]. 2005 [acesso 5 jun 2010]; 31(2):189-99. Disponível em: http://www. scielo.br/pdf/ep/v31n2/a03v31n2.pdf

7. Branden N. Autoestima: como aprender a gostar de si mesmo. São Paulo (SP): Saraiva; 2000. 560 p.

8. Bandeira M. Comportamento assertivo e sua relação com ansiedade, locus de controle e autoestima em estudantes universitários. Estud Psicol. [periódico na Internet]. 2005 [acesso 5 abr. 2010]; 22(2): 111-21. Disponível em: http://www.scielo.br/pdf/estpsi/v22n2/ v22n2a01.pdf

9. Dini GM, Quaresma MR, Ferreira LM. Adaptação cultural e validação da versão brasileira da Escala de Autoestima de Rosenberg. Rev Soc Bras Cir Plást. [periódico na Internet]. 2004 [acesso 20 jun 2010]; 19(1): 41-52. Disponível em: http://www.rbcp.org.br/ imageBank/PDF/19-01-04pt.pdf

10. Vargas TVP, Dantas RAS, Gois CFL. A autoestima de indivíduos que foram submetidos à cirurgia de revascularização do miocárdio. Rev Esc Enferm USP. [periódico na Internet]. 2005 [acesso 10 jun 2010]; 39(1): 20-7. Disponível em: http://www.scielo.br/pdf/ reeusp/v39n1/a03v39n1.pdf

11. Paez D. Constructing social identy: the role of status, collective values, collective self-esteem, perception and social behavior. In: Deschamps JC, Worchel S, Morales JF, editors. Social identity: international perspectives. London: Sage Publications; 1998. p. 211-29.

12. Codo W. Educação: carinho e trabalho. Petrópolis (RJ): Vozes; 1999. 245 p.

13. Schieman S, Campbell JE. Age variations in personal agency and self-esteem: the context of physical disability. J Aging Health. [periódico na Internet]. 2001 [acesso 18 ago 2010]; 13(2): 155-65. Disponível em: http://www.ncbi.nlm.nih.gov/pubmed/11787510

14. Weinberg RS, Gould D. Fundamento da Psicologia do esporte e do exercício. 2ed. Porto Alegre (RS): Editora Artmed; 2001. 284 p.

15. Pachane GG. Teoria e prática na formação pedagógica do professor universitário: elementos para discussão. Publ UEPG Ci Hum, Ci Soc Apl, Ling, Letras e Artes [periódico na Internet]. 2005 [acesso 25 jun 2010]; 13(1): 13-24. Disponível em: http://www.uepg. br/propesp/publicatio/hum/2005_1/02.pdf
16. Ministério da Saúde (BR). Representação no Brasil da OPAS/OMS. Doenças relacionadas ao trabalho: manual de procedimentos para os serviços de saúde na atenção à saúde do trabalhador. Brasília (DF): MS; 2001. p. 19-26.

17. Heckert AL. A dimensão coletiva da saúde: uma análise das articulações entre gestão administrativasaúde dos docentes, a experiência de Vitória. In: Brito J, Barros E, Neves MY, Athayde M, editors. Trabalhar na escola? Só inventando o prazer. Rio de Janeiro (RJ): Edições IPUB; 2001. p. 123-62.

18. Bettancourt L, Muñoz LA, Merighi MAB, Santos MF. O docente de enfermagem nos campos de prática clínica: um enfoque fenomenológico. Rev. Latino-Am. Enfermagem [periódico na Internet]. 2011 [acesso 7 set 2012]; 19(5): 1197-204. Disponível em: http://www. scielo.br/pdf/rlae/v19n5/pt_18.pdf

19. Burke RJ, Greenglass ER, Schwarzer R. Predicting teacher burnout over time: effects of work stress, social support and self-doubts on burnout and its consequences. Anxiety, Stress Coping. 1996;9(3):261-75.

20. Jardim R, Barreto SM, Ávila A. Condições de trabalho, qualidade de vida e disfonia entre docentes. Cad Saúde Pública. [periódico na Internet]. 2007 [acesso 23 abr 2010]; 23(10): 2439-61. Disponível em: http://www. scielosp.org/pdf/csp/v23n10/19.pdf

21. Cox T, Rial-González E. Work-related stress: The European picture. Magazine European Agency Safety and Health at Work [Internet]. 2002 [acesso $10 \mathrm{abr}$ 2010]; 5:4-6. Disponível em: http://osha.europa.eu/ en/publications/magazine/5

22. D’antola A. A prática docente na universidade. São Paulo (SP): EPU; 1992. 187 p.

23. Schwartzman S. A Revolução Silenciosa do Ensino Superior. In: Durham ER, Sampaio H, editors. O Ensino Superior em Transformação. São Paulo (SP): Núcleo de Pesquisas sobre Ensino Superior/USP; 2001. p. 12-35.

24. Greemglass ER, Burke RJ. Hospital downsizing, individual resources, and occupational stressors in nurses. Anxiety, Stress and Coping. 2000;13(4):371-90. 25. Tavares JP, Beck CLC, Magnago TSBS, Zanini RR, Lautert L. Distúrbios psíquicos menores em enfermeiros docentes de universidades. Rev. Latino-Am. Enfermagem. [periódico na Internet]. 2012 [acesso 31 jul 2012]; 20(1): 175-82. Disponível em: http://www. scielo.br/pdf/rlae/v20n1/pt_23.pdf. 